\title{
A Simple External Fixator to Treat Complex Finger Fractures
}

\author{
Ricardo Monreal* \\ Centro Medico MEDEX, San Isidro-Lima, USA
}

Submission: December 19, 2017; Published: January 22, 2018

*Corresponding author: Ricardo Monreal, Centro Medico MEDEX, Republica de Panama 3065 2do piso, San Isidro-Lima, Clinicas Maison de Sante, Ave Chorrillos 171, Chorrillos, Lima, Peru, USA, Email: rmonreal59@yahoo.es

\begin{abstract}
Introduction: External fixation offers an effective treatment option in the management of complex fractures of the phalanges and a variety of external fixators is available for this purpose. We describe a stable, 'easy to construct' external fixator which can be used in an emergency setting, and possibly as a definitive fixation device.

Materials and Methods: Twelve patients suffering complex phalangeal fractures were included in the study. The phalangeal fractures included were mostly comminuted, unstable or open fractures of hand

Results: All of the 12 patients were male. According the Belsky's criteria 25\% patients exhibited excellent results and $66.6 \%$ showed good results.

Conclusion: This effective, 'easy to construct' fixator is recommended in the management of fractures involving the small bones of the fingers where commercial external fixators are not available or the expertise at using them is lacking.

Keywords: Hand; Proximal phalanx; Middle phalanx; Fractures; External fixator
\end{abstract}

\section{Introduction}

Complex fractures of the phalanges involve highly comminuted fractures with significant intraarticular extension may present as open fractures with associated neurovascular damage, tendon injury and sometimes with a fracture dislocation of the adjacent joint. External fixation offers an effective treatment option in the management of these difficult fractures and a variety of external fixators are available for this purpose. We describe a stable, 'easy to construct' external fixator which can be used in an emergency setting, and possibly as a definitive fixation device to treat a variety of complex phalangeal fractures often difficult to manage by someone who does not specialize in hand surgery using the most basic instruments that are readily available at anytime, anywhere in the hospital. The technique is described below.

\section{Patients and Methods}

Twelve patients suffering complex phalangeal fractures were included in the study. The phalangeal fractures included were mostly comminuted, unstable or open fractures of hand (Figure 1).

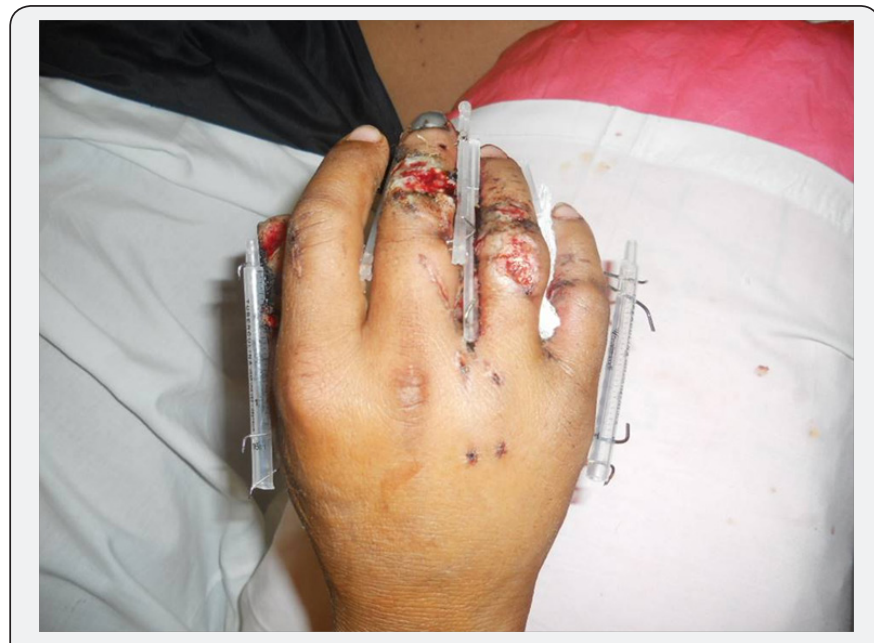

Figure 1: Complex fractures of proximal phalanx treated with Syringe fixator.

\section{Procedure}

All that is required for this procedure are $1.6 \mathrm{~mm} \mathrm{~K}$-wires and an empty syringe barrels (3cc, $5 \mathrm{cc}$ or $10 \mathrm{cc}$ ) (Figure 2). The 
number of K-wires to be applied on either side of the fracture depends upon the fracture pattern and fracture site. The procedure was done in local anaesthesia (digital block). The $\mathrm{K}$ wire was first passed through the barrel and inserted on either side of the fracture site just lateral to the central slip of extensor tendon while the assistant was holding the finger in traction and the reduction was checked under image (Figure 1). Gauze dressings were placed on the pin sites and other open wound if present. Appropriate antibiotics and analgesics were given. The joints above and below were allowed to move passively and actively during the postoperative period. Patients were again reviewed at the end of 8 weeks. Results were analyzed by Belsky's criteria [1] and were graded as excellent (pain-free union/no deformity/total active motion (TAM) $>215^{\circ}$, good (pain-free union/ minimal deformity/ $\mathrm{TAM}>180^{\circ}$ ) and poor ( pain or non-union/ deformity affecting function or cosmesis/ $\mathrm{TAM}<180^{\circ}$. Gingrass criteria were used for assessment of thumb injuries and were graded as excellent (palmar-abduction (PAB) $>45^{\circ} /$ total flexion $\left.(\mathrm{TF})>100^{\circ}\right)$, good $\left(\mathrm{PAB}>30^{\circ} / \mathrm{TF}>75^{\circ}\right)$ and poor- $\mathrm{PAB}<30^{\circ} / \mathrm{TF}<75^{\circ}$ ) [1].

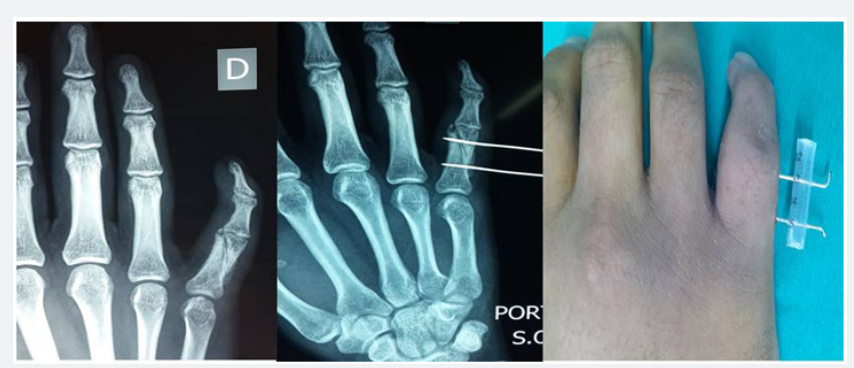

Figure 2: Pre op x-rays and Post-op x-ray showing the implant.

Results

All of the 12 patients were male. Commonest site was middle phalanx in (58.3\%) (Table 1). Using Belsky's criteria 25\% patients exhibited excellent results and $66.6 \%$ showed good results (Table 2).

Table 1: Complex hand fractures- Phalanges involved.

\begin{tabular}{|c|c|}
\hline Phalanges involved & No (\%) \\
\hline Proximal phalanx & $4(33.3 \%)$ \\
\hline Middle phalanx & $7(58.3 \%)$ \\
\hline Thumb & $1(8.3 \%)$ \\
\hline
\end{tabular}

Table 2: Results according to Belsky's criterion.

\begin{tabular}{|c|c|}
\hline Results & No (\%) \\
\hline Excellent & $3(25 \%)$ \\
\hline Good & $8(66.6 \%)$ \\
\hline Poor & $1(8.3 \%)$ \\
\hline
\end{tabular}

\section{Discussion}

Most phalangeal fractures are treated conservatively. Patients with unstable fractures require operative reduction and stabilization to obtain the optimal position for bone healing and to allow early movement. Open reduction and internal fixation may not be suitable in comminuted fractures due to the small size of fracture fragments and it is also not ideal when there is risk of infection due to open wounds and when further soft tissue damage is to be avoided. External fixation remains an important treatment modality in such case.

Commercial external fixators although versatile, they are expensive and need considerable amount of expertise in its application [2,3]. Various innovative and improvised external fixators have been described to treat these complex hand fractures [4-6]. The technique of external fixation using K-wires bonded with methylmethacrylate resin was first described by Crockett [7] in 1974. These early fixators lost popularity as they were cumbersome and not ideal for hand fracture treatment. McCulley \& Hasting [8] described the use of the plastic sheath of an intravenous cannula as a crossbar to hold K-wires in place.

The fixator we have described is an ideal temporary device that prevents soft tissue contracture while allowing for the wounds to heal and planning for definitive fixation. However, in many situations, this improvised fixator can be used in the definitive management of fractures. This effective, 'easy to construct' fixator is recommended in the management of fractures involving the small bones of the fingers where commercial external fixators are not available or the expertise at using them is lacking.

\section{References}

1. Margic K (2006) External fixation of closed metacarpal and phalangeal fractures of digits: A prospective study of one hundred consecutive patients. J Hand Surg Br 31: 30-40.

2. Aro HT, Hein TJ, Chao EY (1990) Mechanical characteristics of an upper-extremity external fixator. Clin Orthop 253: 240-250.

3. Schuind F, Cooney WP $3^{\text {rd }}$, Burny F, An KN (1993) Small external fixation devices for the hand and wrist. Clin Orthop 293: 77-82.

4. Jehanzaib Shah, ObaidurRahman, Riaz Ahmad, Muhammad Ali Bashir, Imtiaz Shakir, et al. (2015) Phalangeal Fractures- Management by Cost Effective Syringe Fixators. Journal of Rawalpindi Medical College (JRMC) 19(2): 133-135.

5. Roshin K Thomas, Rajinder S Gaheer, Rupert D Ferdinand (2008) A simple external fixator for complex finger fractures. Acta Orthop. Belg 74(1): 109-113.

6. Vinayagam Lenin Babu, Komarasamy Baskaran, Andrei Kocialkovski (2005) External fixation of finger fractures made simple. Acta Orthop. Belg 71(3): 347-348.

7. Crockett DJ (1974) Rigid fixation of bones of the hand using K wires bonded with acrylic resin. Hand 6(1): 106-107.

8. McCulley SJ, Hasting C (1999) External fixator for the hand: a quick, cheap and effective method. J Royal Coll Surgeons Edinb 44(2): 99-102. 
Your next submission with Juniper Publishers will reach you the below assets

- Quality Editorial service

- Swift Peer Review

- Reprints availability

- E-prints Service

- Manuscript Podcast for convenient understanding

- Global attainment for your research

- Manuscript accessibility in different formats ( Pdf, E-pub, Full Text, Audio)

- Unceasing customer service

Track the below URL for one-step submission https://juniperpublishers.com/online-submission.php 